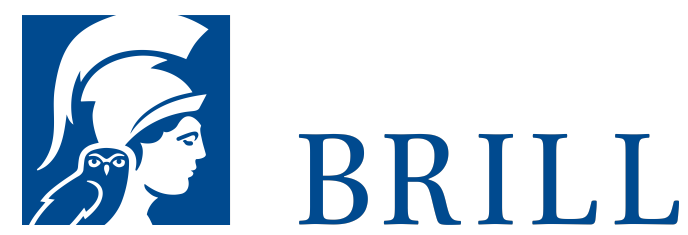

\title{
Reflektierter Intuitionismus
}

\section{Author: Richard Raatzsch}

Wenn etwas wirklich neu ist, geschieht es oft, dass wir nicht wissen, was zu tun gut wÃđre, was schlecht oder bÃ $\llbracket$ se. Ã ,hnlich verhã alt es sich in tragischen Situationen. Beide FÃ schlie ÃŸlich die Form moralphilosophischen Ãœberlegens annehmen. Stellt man solche Ãœberlegungen an, legt sich die Idee eines ethischen Systems fast von selbst nahe. Was aber kÃ $\llbracket n n t e f \tilde{A} 1 / 4$ r ein solches System den Grundsatz liefern? - Hier greifen viele Philosophen auf sogenannte â€žIntuitionenâ€œ zurÃ $1 / 4 c k$. - Warum das vielleicht keine so gute Idee ist, aber dennoch das Beste, was man tun kann, soll in diesem Buch untersucht werden. Dabei kommen eine Reihe von Themen zur Sprache, wie etwa das Gewissen oder die Rolle moderner wissenschaftlicher Methoden fã $1 / 4$ r die Moralphilosophie.

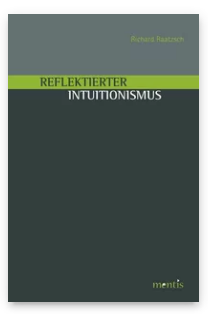

Pages: 135

Seiten

Language:

German

Subjects:

General,

Philosophy

Publisher: Brill | mentis

E-Book (PDF)

Released online:

O5 Dec 2013

ISBN: 978-3-

89785-984-5

List price

Paperback

Publication date:

o5 Dec 2013

ISBN: 978-3-

89785-839-8

List price 
For more information see brill.com

Order information: Order online at brill.com +44330 333 0049 | customerservices@brill.com Submission information: brill.com/authors

Titles published by Brill | Fink, Brill | mentis or Brill | Schöningh: +49(o)715413279216| brill@brocom.de 